\title{
The Prospective Study of Driving Factors on Industrial Estate Environmental Management Policy, Case Study of Industrial Estate in Bekasi Regency
}

\author{
Temmy Wikaningrum ${ }^{1,}{ }^{*}$, and Rijal Hakiki ${ }^{1}$ \\ ${ }^{1}$ Environmental Engineering Department, President University, 17550 Bekasi, Indonesia
}

\begin{abstract}
Pertinent strategic policy required in the environmental management for industrial estate to conduce sustainable management.Due the complexity of the problems, the MDS (Multi Dimensional Scaling) analysis was required in term ofthe dimension of ecological, economical, social, technological and institutional. Prior researches about environmental management analysis in the industrial estate at Bekasi, MDS had been conducted with different approach such as the green rating of PROPER KLHK criteria, integration of quality system and environmental, and expert judgment. The key factors from MDS analysis merged for further study in prospective analysis. It was aim to gain the information about the driving factors which determine the behavior in the system based on the needs analysis of the stakeholders involved. The driving factors were used to form the basis scenario for developing the several prospective alternative strategic policies. The driving factors were taken from the $1^{\text {st }}$ quadrant of mapping result in the depth interview with Bourgeois matrix as low dependency factor but has high impact. The pessimistic, moderate and optimistic alternative prospective strategic policy had been developed. Based on the evaluation of prospective option, optimistic alternative scenario was recommended as the implementative strategy which support the sustainable industrial estate environmental management.
\end{abstract}

\section{Introduction}

The sustainable environmental management for industrial estate is required for Indonesian society in accordance with the high industrial growth and the broad impacts for ecology, economy and social. The suitable technology support and environmental management system are also required. The analysis of sustainability status for several industrial estate had been conducted by various researcher in 5 dimensions, that $\mathrm{s}$ economical, ecological, social, technological and institutional (management). Prior research at Industrial Estate Jababeka showed that the environmental management had been sustainable for institutional dimension, but not yet sustainable for social, economical, technological and ecological [3] and [13]. While the research at East Jakarta Industrial 
Estate Park located at Bekasi Regency showed that it had been sustainable for all dimensions [2].

Further analysis for 53 key factors resulted from prior analysis of multidimensional scaling (MDS) conducted in this paper. The research performed through in-depth interview approach by preferred experts using Bourgeois questionnaire matrix format. The aim of this research is to determine the alternative prospects-strategic policies for sustainable environmental management of industrial estates .

\section{Materials and Methods}

There were several steps required to answer the aim of this research, including research approach, sampling and data processing; techniques of experts selection and procedure for in-depth interview and discussion with experts; and then analyze the data through prospective analysis method. These matters will be discussed further as follows.

\subsection{Research Approach, Sampling and Data Processing}

The industrial estates which located at Cikarang, Bekasi regency had been selected as the location for this research, which had been conducted from Juli 2017 - December 2017.The strategic policy was developed to gain the applied, multi-dimension environmental management policy which involve stakeholders as well as cross-sector studies. Modified rapfish (the rapid appraisal of fisheries status) software had been used in data processing for secondary data with MDS approach to determine the key factors. Green rating PROPER KLHK [13]; integration of quality and environmental management system [3]; and expert judgement [2] were the criteria used for this approach. Primary data from 8 preferred experts has been collected through in-depth interview method which originated from various stakeholders such as government, industries and the public figure. Bourgeois matrix was used to process the scores form normalized collected data to determine the driving factor and leverage factors of theindustrial estate environmental management policy.

\subsection{Techniques of Determining Respondents and Procedure for Discussion with Experts}

The preferred experts for this research were the selected by design (purposive sampling). Because of the techniques used was "digging the information and knowledge of the expert so that this method classified the expert judgment method. The questionnaire was filled out by 8 prefer red experts, consists of social public figure, industries, Government of West Java Province and industrial estate managers with minimum 15 years experience in their field. Several consideration in selection of the experts should be meet the following criteria : 1) Have the competency and experience in the field under study; 2) Existence, affordability and availability to be interviewed; 3) Have a reputation, position and show credibility as an expert in the field under study; 4) Objective and willing to open mind

\subsection{Data Analysis with Prospective Analysis Method}

The collected data from previous research then processed with the modified Microsoft Excell for prospective analysis calculation. The prospective analysis was used to develop strategic action plan required to do and to see the need for future changes[6]. Stages of 
prospective analysis according to Bourgeois and Jesus [1] is as follows: 1) Determine the aim of the study that specifically studied and can be understood by all experts; 2) Identifications of influential factors for purpose achievement, commonly the need of stakeholders under study; 3)Influence between factors is given a score by the preferred experts using perspective analysis guidelines from 0 (the lowest) and 5 ( the higest), with the following stages: 1) Identify factors that are potentially key factors. In Table1 format expressed in A, B, C, etc. [5]. This factors obtained from key factors of analysis MDS.

Table 1. Matrix of direct influence between factors.

\begin{tabular}{|c|c|c|c|c|}
\hline & A & B & C & D \\
\hline A & & & & \\
B & & & & \\
C & & & & \\
D & & & & \\
\hline
\end{tabular}

Results of key factor analysis (figure 1) have a meaning in accordance with the presence in the quadrant where the key factor is located, that is: 1) Quadrant I (Input), contains factors that have a strong influence with the level of dependence is less strong. These factors are the most powerful driving factors (driving variables) in the system; 2) Quadrant II (Stakes), contains factors that have strong influence and strong dependency (leverage variables). These factors are the powerful factors; 3) Quadrant III (Output), contains factors that have a weak influence with the level of dependence is strong; 4) Quadrant IV (Unused), contains factors that have weak influence and weak dependency [1].

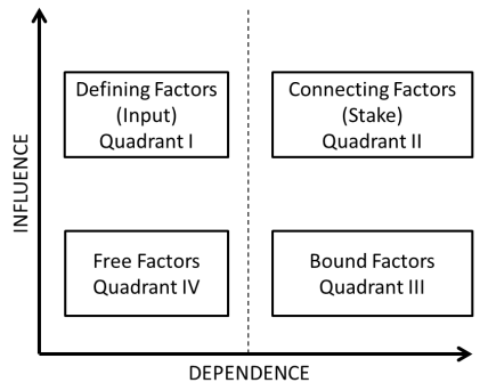

Fig. 1. Influence and dependence diagram.

\section{Results and Discussions}

From the results of prospective analysis on the values that have been normalized for ecological dimension show that there were 3 determining factors as driving force in Quadrant I, that were : a) 3R Implementation of hazardous waste; b) industrial wastewater quality; and c) Industrial estate wastewater quality. It showed that environmental contamination caused by wastewater and hazardous waste a major concern rather than air contamination and greening. Calculation results of prospective analysis for economical dimension showed that there was just 1 factor which becomes the driving factor that is industrial water demand factor. There are 6 leverage (connecting) factors in quadrant II, those are: a) Allocation of water conservation fund; b) Allocation of implementation for environmental management system fund; c) Industrial estate maintenance charge; d) Clean water fare; e) Product exhibition; f) Availability of raw water for clean water. It showed 
that the amount of clean water demand becomes the prime driving factor on economical dimension. Prospective analysis results for social dimension shows that there was just 1 driving factor, while 4 leverage factors according to quadrant II, those were : a) Monitoring and evaluation of community empowerment programs by industrial estate management ; $b$ ) Social relationship of industrial estate management internally and externally; c) Employee turnover in industry; and d) Local employment. It showed that the potential that affected social sustainability was more determined by the conditions of workers in each industry than the local community, social communication and security.

The analysis results for technological dimension showed that there were no factor becomes a driving factor, while there were 4 leverage factors, those were :a) Technology for energy efficiency; b) Technology for 3R hazardous waste; c) ISO14001; and d) ISO9001.The absence of driving factors indicate adequate access to technology has been obtained in the industrial estate under study, which show global phenomenon with easy access to information. While energy efficiency was a concerning issue related to cost saving in energy utilization, as well as enhancement of corporate image. The ISO9001 on the quality assurance system and ISO14001 on environmental management was of concern because in addition to improving the trust of industrial customers, as well as the quality control management system and environmental management required by industrial companies. The analysis results for Institutional dimension showed that there were no factor becomes a driving factor, while there were 4 leverage factors, those were : a) Benchmarking for environmental management system; b) DRKPL (Environmental Performance Report Document) industrial estate; c) Industrial estate regulations; and d) Compliance of environmental quality management requirements.

The over all prospective analysis results for 5 dimension showed that there were 5 factors which originated from 3 dimension, those were ecological, economical and social becomes a driving forces in a sustainable industrial estate environmental management system. While for technological and institutional dimension, there were no driving factors, even though there were many connecting factors as a leverage factor.

Environmental management scenario of industrial estate was based on the driving factors that have strong influence with low value of dependency as driving force on environmental management of industrial estate. There were three possibility in performance for driving factor that may occur in the future, which were fixed, increased or decreased. From these various possibilities, then compiled a combination of defining factors which can not simultaneously occur when the management system is well implemented. Such a nonpossible combination is eliminated in the preparation of further scenario. The preparation of scenario is intended to predict the likelihood that may occur in the factor, wether it will progress to a better direction from now, remain, or will be worse than the present [6]. Pessimistic scenario, moderate and and optimistic scenarios had been developed according to mapping results with 2017 data as the baseline.

The pessimistic scenario means the industrial wastewater quality from industries getting worst that impact decreasing quality of treated wastewater from industrial estate management. Meanwhile, 3R program of hazardous performance also decrease and labour condition is less conducive. In this scenario, the economic performance will also decline that impact lower industrial water demand.The moderate scenario means the industrial wastewater quality from industries getting better that impact increasing quality of treated wastewater from industrial estate management. Meanwhile, there is no improvement in 3R program of hazardous performance and labour condition. In this condition, the industrial water demand may increase that can impact better economic performance of industrial manager.The optimistic scenario means, all driving factors are increase and supporting each other as positive relationship. 


\section{Conclusion}

Referring to the research results, recommendation for optimistic scenario is the most preferred option to do. That is with the strategic step that begins by improving the quality of wastewater from each industry who as the tenant of industrial estate management. In this case, synergy between the industrial estate management and each tenant is required. Industrial wastewater quality improvement will result positive impact with the better quality of industrial estate wastewater, which will increase customer trust, government and banking to support economic and business conditions of the industry and industrial estate managers. Improvement on economical dimension should be followed by social dimension improvement, for sustainable environmental management [8].

\section{References}

1. Bourgeois R., Jesus F, Participatory prospective analysis : exploring and anticipating challenges with stakeholders, (CAPSA Monograph No. 46, United Nation, 2004)

2. Budiyanto P, Saefuddin A, Putri EIK. J. Pengeloaan Sumber daya alam dan Lingkungan 5, 2 (2015)

3. Cahyanto AD, Noorachmat BP, Noor E. J. Pengeloaan Sumber daya alam dan Lingkungan 6, 1 (2016)

4. Dynasty AW, Purwanto, Anggoro DD. Strategi Pengembangan Kawasan Industri berwawasan Lingkungan (Eco Industrial Park) pada Zona Industri Pringapus. Tesis Universitas Diponegoro (2017)

5. Godet M, Scenarios and Strategies, A Toolbox for Scenario Planning, (Librairie des Arts es Meiters, Paris (FR), 1999)

6. Hardjomidjojo H, Metode analisis prospektif, (Departemen Teknologi Industri Pertanian Fakultas Pertanian Institut Pertanian Bogor, IPB Press, Bogor, 2002)

7. Kuznetsova Z, E. Farel R. J. of Cleaner Production 126 (2016)

8. Park, JM, Park JY, Park HS. J. of Cleaner Production 114 (2016)

9. Marimin, Aplikasi teknik pengambilan keputusan dalam manajemen rantai pasok, (IPB Pres, Bogor, 2013)

10. Nastase M, Radu (Gherase) C, Tapurica, OC, Tache F. Seria Management 13, 2 (2010)

11. Saaty TL. Int. J. Services Sciences 1, 1 (2008)

12. Sosnovskikh S. Role The Government un the Development of Special Economic Zones and Industial Parks in Russia. The 11th International Days of Statistics and Economics, Prague (2017)

13. Wikaningrum T, Noorachmat BP, Noor E. J. Pengelolaan Sumber daya alam dan Lingkungan 5, 2 (2015) 